\title{
Darbības vārda sintaktiskās nullformas latviešu valodā
}

\section{Syntactic zero forms of verbs in Latvian}

\author{
Ilze Lokmane \\ Latvijas Universitāte, Humanitāro zinātņu fakultāte \\ Latviešu un vispārīgās valodniecības katedra \\ Visvalža iela 4a, Rīga, Latvija \\ E-pasts: ilze.lokmane@lu.lv
}

\begin{abstract}
Rakstā aplūkotas dažādas nulles zīmes izpratnes valodniecībā, īpaši nullformu interpretācija morfologijā un sintaksē. Teikuma paradigmas sakarā nozīmīga ir finītā verba nullforma, jo nullformas postulēšana palīdz noteikt sintaktiskās paradigmas robežas, respektīvi, norobežot atškirīgas viena model̦a realizācijas no dažādiem model̦iem.

Latviešu valodā ir iespējama gan palīgverba, gan saitinas, gan patstāvīgā nozīmē lietota $b \bar{u} t$ nullforma, tomēr obligātu finītā verba nullformu nevienā paradigmas formā nav. Nullforma îstenojas konsituatīvi nesaistītos teikumos un ir šķirama no sintaktiskās redukcijas, jo pretējā gadījumā zūd atšksirība starp sintaktiskiem procesiem tekstā un regulāriem pārveidojumiem teikumā.
\end{abstract}

Atslēgvārdi: nulles zīme, nullforma, paradigma, sintaktiskā redukcija, potenciāli verbāls teikums.

\section{Nulles zīmes izpratne valodniecībā}

Valodas zīme, kā zināms, ir divpusēja - apzīmējošais jeb apzīmētājs ir zīmes akustiskais tēls vai fonētiskā realizācija, savukārt apzīmējamais ir nemateriāls saturs jeb nozīme. Nulles zīme plašā izpratnē ir zīme, kurai nav apzīmētāja, tātad nav fonētiskas realizācijas, bet ir nozīme.

Dažādās valodniecības terminu vārdnīcās nulles zīmes izpratne ir līdzīga. Nulle (zero) ir elements, kas tiek postulēts kādā reprezentācijas līmenī, bet kura realizācija ir nulle, proti, kam nav fonētiskas realizācijas (Matthews 1997, 409, 250). Nulle (zero) ir abstrakta vienība, kam runas plūsmā nav fiziskas realizācijas, tā tiek saukta arī par nulles elementu (null element) (Crystal 1999, 372). Nulles(nulevoi) (negatīvs) ir tāds, kas veic noteiktu lingvistisku (semioloğisku) funkciju bez speciālas (skaniskas) izpausmes, tikai pretstatā realizētiem (pozitīviem) tās pašas rindas vai paradigmas elementiem (Ahmanova 2005, 272). Tātad nulles elements iegūst nozīmi tikai pretstatā formāli iezīmētiem opozīcijas locekḷiem.

Konkrētās nulles vienību izpausmes atkarībā no pētnieka pieejas un pētāmās valodas var būt l̦oti daudzveidīgas. Piemēram, lietvārda frāzē ø women anglu valodā tiek postulēts nulles artikuls jeb determinētājs pretstatā frāzēm $a$ woman un the women; nulles relatīvais vietniekvārds palīgteikumā The men [ø I saw] pretstatā The men [who I saw]; par nulles derivāciju vārddarināšanā tiek saukta 
konversija; nulles morfēma ir morfēmas alomorfs, kura patiesībā nav; par nulles valenci runā gadījumos, kad verbs nevar piesaistît nevienu argumentu (kā puteņot, piesalt) (Matthews 1997, 409); nulles anafora teikumā Susie needs a new car but $\varnothing$ doesn't have the money (Trask 2005, 13); nulles infinitīvs bez nenoteiksmes rādītāja to angḷu valodā (Crystal 1999, 162); nulles subjekts tiek postulēts valodās, kurās teikuma priekšmeta realizācija nav obligāta (Matthews 1997, 250); nulles saitiņa tagadnes īstenības izteiksmes formā krievu valodā (Ahmanova 2001, 396) utt. Nulles vienības tiek postulētas arī dažādās konstrukcijās ar infinitīvu un divdabjiem, piemēram, kontroles konstrukcijās (Testelec 2001, 270-276):

(1) Lūdzu, ø aizejot neaizmirstiet ø izslēgt apgaismojumu! (www.celotajs.lv)

Igors Mel̦čuks (Igor' Mel'chuk 1995, 189) norāda, ka nulles terminoloǵija lingvistikā ir plaši lietota un aiz tās slēpjas dažādas valodas parādības. Viṇš neiesaka lietot šo terminu tādā nozīmēe, kā, piemēram, nulles vārdu secība, kas patiesībā ir neitrāla, vai nulles valence, kas ir valences trūkums.

Tātad nulles zīmes eksistenci pamato:

1) nozīme, ko tā izsaka (motivācija „no apakšas” jeb zemāka vai dziḷāka līmeņa vienībām, sk. Mel'chuk 1995, 176),

2) attieksmes ar citām tās pašas paradigmas vienībām,

3) kombinatoriskās jeb sintagmatiskās īpatnības jeb distribūcija (motivācija „no sāniem”, sk. Mel'chuk 1995, 176).

Pirms pievēršamies nullformu izpratnei un tipiem sintaksē, lietderīgi pieminēt, kādas nulles zīmes tiek postulētas otrā gramatikas daļā - morfoloǵijā. Nulles morfēma ir ,paradigmas elements, kam nav formālas izpausmes un kas funkcionē kā gramatiskas formas pazīme, piemēram, latviešu valodā nulles morfēma darbības vārdu dziedāt, redzèt, mīlèt vienkāršās tagadnes 3. personas formā dzied-ø, redz-ø, mīl-ø vai arī lietvārdu māte, têvs, māsa vokatīvā māt-ø!, tềv-ø!, mās-ø!" (Skujiṇa 2007, 265).

Pēc analog̣ijas arī sintaktiskā nullforma, piem., slāvu valodniecībā, tiek postulēta gadījumos, kad noteiktā teikuma formā kādas vārdformas fonētiskā realizācija nav iespējama, piem., saitiņas būt nullforma tagadnē un indikatīiā krievu valodā (Mel'chuk 1995, 176):

(2) On krasiv.

'Viňš ir skaists'

Par sintaktiskās nulles esamību liecina gan pārējās - realizētās - vārdformas teikumā (sintagmatiskais aspekts), gan citas teikuma formas (paradigmatiskais aspekts) (Mel'chuk 1995, 176):

(3) On budet krasiv.

'Viņš būs skaists'

Šādā izpratnē sintaktiskā nullforma, tāpat kā nulles morfēma vai nulles morfs, ir obligāta. Kā norādījis Jakovs Testel̦ecs (Jakov Testelec 2001, 276), ar ìstu nullformu mums ir darīšana tad, ja valodā nav pilnībā sinonīmiska formāla (jeb „ne-nulles”) izteikšanas pan̄ēmiena. Tomēr jāpatur prātā, ka analoǵija starp 
morfologiju un sintaksi nekad nevar būt pilnīga, jo atšķirības starp tām ir būtiskas (Mel'chuk 1995, 176).

\section{Nulles zīmes sintaksē}

Sintaktisko nullformu problemātika ir aktuāla sintakses parādību sistēmiskuma aspektā. Nullformu postulēšana palīdz noteikt sintaktiskās paradigmas robežas, proti, norobežot viena model̦a dažādas (pilnas un nepilnas) realizācijas no atšksirīgiem sintaktiskiem modeliem. Tā kā teikuma modeli veido gramatiskais centrs, rakstā tiks aplūkotas tikai iespējamās finītā verba nullformas latviešu valodā.

„Valodniecības pamatterminu skaidrojošajā vārdnīcā” (Skujiṇa 2007, 265) nullforma definēta šādi: „Formālas izpausmes trūkums kādai vārdformai, kas veic kādu sintaktisku funkciju un konstatējama pretstatā formāli izteiktiem tās pašas paradigmas elementiem. Latviešu valodā iespējama saitinas nullforma, piem., Tagad viss [ir] citādi, pal̄̄gdarbības vārda nullforma, piem., Viņš jau [ir] ieradies, un patstāvīga darbības vārda būt nullforma, piem., Ietves malā [ir] papīi un cigarě̌u gali."

Latviešu valodā visos definīcijā pieminētajos gadījumos iespējama arī pilnā forma, neviena no šìm nullformām nav obligāta. Daļa autoru neobligātu nullformu gadījumos iesaka lietot terminu elipse, kam latviešu lingvistiskajā tradīcijā atbilst sintaktiskā redukcija. Elipse resp. redukcija ir likums, kas lauj izlaist noteiktas zīmes noteiktā kontekstā, un tās cēlonis ir valodas līdzekḷu pārdaudzums, proti, šīs zīmes ir informatīvi liekas (Mel'chuk 1995, 193).

Igors Mel̦čuks (1995, 170-173) iesaka sintaksē šķirt nulles vārdformas jeb nulles leksus un nulles leksēmas pēc analoǵijas ar nulles morfu un nulles morfēmu. Nulles morfs ir viens no morfēmas alomorfiem, bet, ja vienīgais alomorfs ir nulle, tad tā ir nulles morfēma. Tātad nulles lekss ir, piem., nulles kopula jeb saitiņa tagadnē un indikatīvā krievu valodā. Savukārt nulles leksēmai vispār nav fonētiskas realizācijas, tātad nulles leksēmu var postulēt tikai tajos gadījumos, kad valodā nav "ne-nulles" leksēmas, kas būtu pilnībā sinonīmiska hipotētiskajai nullei (Mel'chuk 1995, 187). (Krievu valodas materiālā autors runā tikai par nulles leksēmām ar nomena semantiku.)

Latviešu valodā verba nulles realizācija nav obligāta nevienā paradigmas formā (tātad verba nullformu, kas būtu analogas nulles morfiem, nav). Vienīgais izñēmums te varētu būt teikumi ar nenoteiksmi izteicējā (un obligātu nullformu tagadnē), piem.:

(4) Ko man darīt? (www.korpuss.lv)

Tie tiks aplūkoti mazliet tālāk šajā rakstā.

Sistēmiskuma aspektā latviešu un arī slāvu valodniecībā tiek runāts par modeḷu nepilnu jeb daḷēju realizāciju kādā paradigmas formā (sk., piem., Kārklinšs 1974; Freimane 1985; Valdmanis 1989; Beloshapkova 1999; Lauze 2004; Lokmane 2013). Izvēle starp pilnu un nepilnu realizāciju ir diezgan brīva, tomēr parasti konstatējamas kādas semantiski un stilistiski nosacītas tendences. Piem., daiḷliteratūras tekstiem raksturīgi teikumi ar eksistenciālu nozīmi bez formāli realizēta izteicēja $b \bar{u} t$, kas citos funkcionālajos paveidos sastopami retāk vai nemaz: 
(5) Turpat [ir] arī Dīdžejs, skaists un bīstams cilvēks. (J. Joṇevs)

Arī šādos gadījumos nullformas jēdziens nav gluži nevietā, atškirība tikai tāda, ka nulles zīmes eksistenci pamato nevis attieksmes pret citām teikuma paradigmas formām (valodas sistēmā), bet pret citām tā paša sintaktiskā modeḷa realizācijas formām (runā). Teikuma modeḷu nepilnās realizācijas formas tomēr vajadzētu šķirt no redukcijas resp. elipses, jo pretējā gadījumā zūd atšķirība starp sintaktiskiem procesiem tekstā un regulāriem pārveidojumiem teikumā.

Sarmīte Lagzdina $(1997,27)$ terminus redukcija un nullforma lietojusi sinonīmiski, bet tas minētā iemesla dēl nebūtu ieteicams: „Latviešu valodā prasībai pēc obligāta finītā verba teikuma sastāvā ir arī daži izņēmumi - teikumi ar reducētu finīto verbu, kuros redukciju nenosaka konkrētā konteksta vai konsituācijas faktori. Arī šādi teikumi ir potenciāli autonomi, taču .. tie nepārstāv atsevišķu teikuma tipu vai modeli, bet to pašu verbālo modeli kā attiecīgie teikumi ar eksplicītiem komponentiem. Reducētais verbs jeb verba nullforma [pasvītrojums mans - I. L.] teikumā pilda tādas pašas gramatiskās, strukturālās un semantiskās funkcijas kā eksplicīts finītais verbs un tādējādi realizē arī gramatisko predikativitāti." Piemēros minēta palīgverba būt īstenības izteiksmes un atstāstījuma izteiksmes vienkāršās tagadnes formas redukcija (6) un (8), teikumi ar patstāvīga verba īstenības izteiksmes vienkāršās tagadnes formas redukciju (7) un (8), kuros par verba nullformas klātbūtni, tā formu un semantiku liecina paša teikuma sastāvs resp. reducētā verba valences nosacītie teikuma komponenti (Lagzdiņa 1997, 27-28):

(6) Pēkšņi kāds [esot] zvanüjis pie durvīm.

(7) Viņš tūlūt [dodas, metas, skrien] pa kāpnēm lejā.

(8) Mežmalā [ir, aug] liels ozols.

Tātad, pēc raksta autores domām, ir pamats runāt par nullformām teikuma model̦u nepilnas realizācijas gadījumos. Tâlāk pievērsīsimies dažādiem darbības vārda nullformu tipiem latviešu valodā.

\subsection{Paligverba un saitinas nullforma}

Kā norāda Inta Freimane (1985, 55), „divkopu teikumos iespējams arī teikumpriekšmeta un izteicēja saistījums bez saitiņas - tikai bez saitinas būt (tad runā par būt nullformu) un tikai apgalvojuma teikumos, kur paralēli iespējama gan forma ar būt, gan bez tā. .. Saitiņas būt nullforma rāda ar izteicēja nominālo daḷu izteiktā nojēguma klātieni, pastāvēšanu, apgalvo, ka tas ir, eksistē”.

Arī Jānis Valdmanis teikuma paradigmas sakarā runā par teikuma modeḷa derivātu ar nozīmīgu saitinas nullformu tādos teikumos kā (9) un (10) (Valdmanis 1989, 85-86):

(9) Diena [ir] saulaina.

(10) [Ir] Pavasaris.

Palīgnozīmē lietota verba būt realizāciju savā promocijas darbā pētījusi Baiba Ivulāne: „Tradicionāli tiek uzskatīts, ka palīgdarbības vārda nullforma iespējama vien̄̄gi 1̄stenības izteiksmes tagadnes 3. personā, taču no konsituācijas var būt izsecināma palīgdarbības vārda nullforma arī citās izteiksmēs, personās un laikos.” 
(Ivulāne 2015, 86) Minēti piemēri ar nullformu atstāstījuma izteiksmē un īstenības izteiksmes pagātnē, dažos gadījumos nerealizētā forma nav skaidri nosakāma:

(11) Viņš stāstīja, ka pārdabiskās parādības [ir / bija / esot] sākušās jau pirmajā dienā pēc viņu ievākšanās savrupmājā. (www.korpuss.lv)

Tā kā palīgverbs kopā ar pilnnozīmes verbu veido vienu analītisku morfologísku formu, palīgverba nullformas gadījumi nebūtu attiecināmi uz sintaksi. Tomēr, pirmkārt, analītisko formu iekḷaušana morfologiskajā paradigmā vai sintaktisku konstrukciju kategorijā ir interpretācijas un daļēji arī gramatiskās tradīcijas nosacīta, otrkārt, kā liecina pētījums, palīgverba un saitiņas nullformu īstenošanās nosacījumi ir līdzīgi.

Saitiņas nullformu Baiba Ivulāne $(2015,88)$ konstatē galvenokārt gadījumos, kad izteikumam ir vispārīga nozīme un nav saistības ar konkrētu laiku:

(12) Pēc kaujas visi ø gudri.

(13) Kāda ø ābele, tāds ø ābols.

Gan palīgdarbības vārda, gan saitinas nullforma bieži sastopama jautājuma teikumos (14), ekspresīvā runā (15), kā arī teikumos ar noteiktu tipu paplašinātājiem - determinantiem un situantiem (16) (piemēri no Ivulāne 2015, 88):

(14) Kāda vairs ø nozīme vecumam?

(15) Cik visi ø jauni un braši!

(16) Viņai ø citas lietas prātā.

Tātad minētajā pētījumā iezīmēti faktori, no kuriem atkarīga pilna vai daḷēja teikuma model̦a realizēšanās.

Jautājums par saitinas nullformu sistēmiskuma aspektā aktualizējas teikumos ar nenoteiksmi izteicēja funkcijā ar saitiņu vai bez tās (par to sk. Lokmane 2014). Kā jau minēts, saitiņa ir obligāta pagātnē un nākotnē, bet nav iespējama tagadnē:

(17) Ko man darīt?

Ko man bija darīt?

Ko man būs darīt?

Tomēr tikai dažos gadījumos iespējams paralēls lietojums visos trīs laikos bez būtiskām pārmaiñām semantikā. Vairumā gadījumu semantisko atšķirīibu dēḷ visas laika formas nav iespējamas:

(18) Tev būs no tā mācīties.

?Tev bija no tā mācīties.

*Tev no tā mācìties.

Visiem teikumiem raksturīga ireāla modāla nozīme. Modālo nozīmju realizāciju ietekmē izteikuma komunikatīvais tips un polaritāte, kas dažādās laika formās izpaužas atšķirīgi. Piem., pamudinājuma teikumiem bez saitiņas piemīt kategoriskas pavēles nozīme (19), kas nākotnes formām nav raksturīga, bet pagātnes formā šādi teikumi vispār nav konstatēti.

(19) Visiem gulēt! (www.tvnet.lv) 
Savukārt negatīvas polaritātes jautājuma teikumi konstatēti tikai bez saitinas, parasti ar jautājamo vārdu $k \bar{a} p \bar{e} c$. Būtībā tie ir nevis nolieguma teikumi, bet gan retoriski jautājuma teikumi, kas īpaši uzsver nepieciešamību:

(20) Kāpēc neiepriecināt ('vajag iepriecināt') kādu ar zivtiņu reizi mēnesī? (www. copeslietas.lv)

(21) Käpēc nedarīt ('vajag darīt'), ja var darīt? (www.diena.lv)

Vērojamas arī stilistiskas atšķirības. Teikumus bez saitiņas varam atzìt par stilistiski neitrāliem, savukārt teikumi ar saitinu (īpaši nākotnes formā) ir stilistiski paaugstināti:

(22) Un tā tam būs būt. (www.korpuss.lv)

(23) Tev būs godāt savu atvērtā koda softu. (www.korpuss.lv)

Rodas jautājums, vai nullformas noteikšanai teikumos ar nenoteiksmi varētu izmantot semantisko kritēriju, proti, to, ka teikumam piemīt saitiņas piešksirtā nozīme. Tomēr saitinas nozīme ir tik vispārīga, ka būtībā līizinās nullei. Turklāt teikumiem bez saitiņas nav ne tagadnes, ne indikatīva nozīmes (kā minēts, tie visi ir ireālā modalitātē), tāpēc saitiņas esamību nevar pierādīt arī semantiski.

Visi minētie apsvērumi liek secināt, ka teikumi ar saitiṇu un bez tās veido dažādus model̦us. Iespējams, ka ir pamats postulēt pat trīs atsevišksus modeļus atkarībā no saitiņas laika formas, bet te būtu nepieciešams pētījumus turpināt, apkopojot plašāku materiālu.

\subsection{Patstāvīga verba būt nullforma}

Latviešu valodniecībā ir dažādi uzskati par to, kā šksirt būt patstāvīgo nozīmi no palīgnozīmes. Proponētas trīs patstāvīgas nozīmes (sk., piem., Freimane 1985, 53; Beitina 2009, 119):

1) eksistenciālā nozīme:

(24) Mūžu mūžos būs dziesma (I. Ziedonis)

2) atrašanās nozīme:

(25) Es tur biju vasarā. (www.korpuss.lv)

3) piederības nozīme:

(26) Mums būs atlaides. (www.korpuss.lv)

Ja patstāvīga būt finītā forma paliek nerealizēta, veidojas potenciāli verbāli teikumi. Šo terminu latviešu valodniecībā ieviesis Jūlijs Kārkliņš (1974, 49-50): „No pārējiem verbāliem teikumiem šādi vienkārši teikumi atšksiras ar to, ka tajos nav eksplicītas (izteiktas) verba formas izteicēja funkcijā. .. Par potenciāliem verbāliem teikumiem sauktas galvenokārt tādas teksta vienības, kurās ir būt (vai tam sinonīma verba) nozīmīga nullforma. Tā tas tādēl, ka tieši šādas teksta vienības ir noteiktās sistēmas attieksmēs ar atbilstošiem eksplicīti verbāliem teikumiem (neatkarīgi no konsituācijas) un būtībā ir eksplicīti verbālo teikumu îpaši varianti [autora pasvītrojumi].” Arī šie teikumi pastāv galvenokārt sintaktiskajā indikatīvā vienkāršajā tagadnē (Freimane 1985, 52). 
Potenciāli verbālos teikumos nav realizēts verbs būt visās trijās patstāvīgajās nozīmēs - eksistenciālā (27), atrašanās (28) un piederības (29) nozīmē:

(27) Citādi [ir] pilnīgs klusums. (V. Janelsiņa)

(28) Abpus tām [ir] tikai mežs. (N. Ikstena)

(29) Kam [ir] prāts, tam [ir] bēdas. (N. Ikstena)

Maigone Beitiņa šādos gadījumos runā nevis par dal̦ēju teikuma model̦a realizāciju, bet gan par eliptisku gramatisko centru ar izlaistu virslocekli, ja bez tā teikums ir informatīvi pietiekams (Beitiņa 2009, 83-84):

(30) Vakarā zālē [būs] koncerts.

(31) Slinkam nedēḷā [ir] septingas svètdienas.

(32) Bagātam visur [ir] gods.

Visbiežāk potenciāli verbāli teikumi ir paplašināti. Tipiski paplašinātāji ir apstāklis ar vietas vai laika nozìmi, kas attiecas uz visu teikumu (situants), kā arī īpašnieka vai izjutēja nosaukums datīvā (determinants), l̦oti bieži abi kopā:

(33) Man rokās [ir] zīmēšanas tāfelīte. (www.korpuss.lv)

Tātad nullformas realizāciju nosaka distribūcija. Ja šādu paplašinātāju nav, potenciāli verbāli teikumi visdrīzāk jāatzīst par kontekstuāli saistītiem, jo eksistenciālā nozīme realizējas vien̄̄gi tekstā:

(34) Centrālā dzelzcel̦a stacija. Vestibils. (L. Gundars)

Turklāt tādā gadījumā potenciāli verbāli teikumi robežojas arī ar nosaucējvienībām (plašāk sk. Lokmane 2005):

(35) Balta zīda naktskrekls! Auskaru kolekcija! Un tas viss priekš trīs dienu konferences! (G. Repše)

\section{Sintaktiskās redukcijas un nullformu attieksmes}

Latviešu valodas gramatikā nullformas jēdziens lietots arī tādos gadījumos, kad vārdformas formālās realizācijas trūkums ir konsituatīvi nosacīts. Kā minēts iepriekš, uz šiem pašiem gadījumiem attiecināts arī redukcijas jēdziens - sintaktiskā redukcija ir ,viena vai vairāku strukturāli nozīmīgu komponentu izlaidums teikumā. Redukcija parasti notiek konteksta, runas situācijas vai konsituācijas ietekmē" (Skujinga 2007, 322).

Piem., Linda Lauze (2004, 78-80), analizējot sarunvalodas materiālu, konstatē predikāta nullformu gadījumos, kad trūkstošās leksēmas nozīme izsecināma saziņas situācijā:

(36) - Dace, tu otrreiz [ienāc kafejnīcā]?

(37) - Es uzreiz [samaksāšu].

(38) - Vèl vienu [konfekti iedod].

Linda Lauze (2004, 79) norāda: „Semantiskā zin̄ā darbības vārda nozīmi atklāj konteksts un/vai ekstralingvistiski faktori, gramatiskā ziņā par verba esamību 
nulles pozīcijā liecina labās un kreisās valences nosacītie izteikuma struktūras komponenti."

Tomēr latviešu sintaksē redukcija tradicionāli tiek uzskatīta par kontekstuālu parādību, turpretim nullformas realizācijā konteksts nav būtisks. Zīmīgi, ka konteksts l̦auj reducēt dažādas semantikas verbus un reducēts izteikums saprotams vienīgi kontekstā, savukārt nulles formā iespējamas tikai verba būt formas, bet to trūkums teikuma semantiku nemaina - tas joprojām ir kontekstuāli neatkarīga, semantiski pietiekama saziņas vienība.

Sintaktisko nullformu, tāpat arī redukcijas sakarā tiek aplūkoti izteikumi, kas veido pārejas joslu starp konsituatīvi saistītiem un konsituatīvi nesaistītiem izteikumiem. Tie ir saprotami bez konteksta, jo uz formāli nerealizēto komponentu semantiku norāda realizētie komponenti, parasti ar adverbiālu nozīmi (par šādiem izteikumiem sarunvalodā sk. arī Lauze 2004, 118-119):

(39) Grāmatas grib [doties] uz mājām! (www.draugiem.lv)

Nerealizēto komponentu nozīmes šādos izteikumos patiešām ir tipiskas un samērā vispārīgas:

1) kustības nozīme:

(40) „Bet nu mudīgi [kāpiet, leciet ...] laukāa! Mēs jau esam nobraukuši labu gabalu garām." (A. Eglīis)

2) došanas vai ņemšanas nozīme:

(41) ,, Glāzi [dod, dodiet ...] šurp!'” (A. Eglītis)

3) runāšanas nozīme, jo īpaši tiešās runas piebildēs:

(42) .. vēl diktāk [teica, sacīja ...] māte. (G. Repše)

(43) .. tā nīgrāk têvs. (G. Repše)

4) l̦oti vispārīga darīšanas nozīme:

(44) Bille gribēja zināt, ko tad [dara ...] Bānītis? (V. Belševica)

Daudzi reducēti izteikumi ir tik tipiski, ka zināšanas par situāciju gandrīz nav nepieciešamas, gluži otrādi - tie paši ietver norādi uz situāciju, kurā šādus izteikumus mēdz lietot. Tas liek domāt, ka šādus izteikumus varētu uzskatīt par teikumu nepilnas realizācijas formām. Tomēr š̄i raksta autore proponējusi tos uzskatīt par konsituatīviem saistījumiem vairāku iemeslu dēḷ (sk. arī Lokmane 2005).

Pirmkārt, šajos izteikumos reducētā komponenta semantika ir tik vispārīga, ka konkrēta leksēma (un bieži arī konkrēta gramatiskā forma) nav nosakāma un nereti ietver pat dažādām leksiski semantiskām grupām raksturīgos semantiskos elementus:

(45) Bibliotēkā vēl vienmēer strādāja tas pats bālais un izstīdzējušais jauneklis. Kādu grāmatu [dot, vajag .. ?] jums? - viņš laipni prasīja. (G. Janovskis)

(46) Ko tad Ciemalda [teica, darīja .. ?]? (A. Eglītis) 
Tāpēc daudzu izteikumu pareizai saprašanai tomēr nepieciešamas arī zināšanas par saziņas situāciju:

(47) Es jau tikai labu [daru, domāju, runāju .. ?]. (www.twitter.com)

(48) Eh ... nu, ko tur [runāt, uztraukties, darīt .. ?]! (www.tvnet.lv)

Arī Daniels Veiss (Daniel Weiss 1995, 206-207), komentēdams Igora Mel̦čuka uzskatus par sintaktisko nulli, pamanījis līdzīgus gadījumus un uzsvēris, ka ne vienmēr ir izlaistas konkrētas leksēmas, drīzāk abstrakti sēmu kompleksi, proti, kaut kas ar lielu nenoteiktības pakāpi, piem., 'darboties'. Šādi teikumi mēdz būt ne tikai leksiski, bet arī gramatiski neskaidri, jo ne vienmēr var rekonstruēt verba veidu un aspektu. Tādējādi termins elipse (resp., redukcija) nav pietiekams, lai aptvertu visus predikāta izlaidumus. Ir kaut kas pa vidu starp nulles leksēmu (kam nav konkrētas sinonīmiskas leksēmas) un elipsi (kas parasti ir konkrēta leksēma).

Otrkārt, daudzos gadījumos saprotamību nodrošina ne tikdaudz pārējie teikuma locekļi, cik tradicionalitāte. Runātājam zināms šo runas formulu tradicionālais lietojums un implicītais saturs. Kā norādījis Jūlijs Kārkliņš (1974, 71), „lai gan teorētiski situāciju skaits ir bezgalīgs, tomēr tipisku situāciju daudzums ir vairāk vai mazāk ierobežots. Katras valodas tradīcijas ietekmē veidojas situatīvi nosacītu teksta vienību tipi ar tiem raksturīgu struktūru".

Treškārt, šādos izteikumos nereti notikušas semantiskas pārvirzes, piem., izteikumi ar ko nu par ... ietver vispārīgu runāšanas nojēgumu, bet tiem ir noteikts slēptais saturs, proti, 'nav vērts par to runāt':

(49) Klausoties sarunu, es nodomāju - ak, ko nu par valsts ministru. Vèl nesen kāds kungs - atcerēsimies - pretendēja uz Valsts prezidenta posteni, ar grūtībām latviešu valodā izrunādams dažus vārdus. (Z. Skujiñš)

(50) Nabadzīgie jūrmalnieki neprasīja maksas ne par lielo kambari, ne pienu, ne jaunajiem kartupeliem. - Ko nu kungs, ko nu par samaksu... (M. Vētra)

Tātad attiecināt nullformas jēdzienu uz šāda tipa situatīvi saistītiem izteikumiem nebūtu lietderīgi.

\section{Secinājumi}

Aplūkotais materiāls l̦auj secināt, ka sintaktisko nullformu identificēšanā un to nošksiršanā no sintaktiskās redukcijas parasti tiek izmantoti šādi kritēriji:

1) nulles zīmes obligātums vai neobligātums,

2) nulles zīmes semantika (darbības vārds būt vai kas cits),

3) izteikuma kontekstuālā atkarība,

4) sintaktiskās paradigmas robežas.

Varam konstatēt trīs dažādas sintaktisko nullformu izpratnes:

1. Nullforma kā obligāts formālās realizācijas trūkums vienā no paradigmas formām. Ja pieņemam šādu izpratni, tad latviešu valodā finītā verba nullformu nav (varētu vien̄̄gi runāt par nomenu nullformām gramatiskā subjekta jeb teikuma priekšmeta pozīcijā, piem., Ø Puteņo, bet tas būtu atsevišksa pētījuma 
temats). Tomēr jāatceras, ka ne vienmēr ir iespējams noteikt sintaktiskās paradigmas robežas, tāpēc nullformas postulēšana ir problemātiska.

2. Nullforma kā teikuma modeḷa nepilna jeb daḹja realizācija, kas nav obligāta; tā vērojama konsituatīvi nesaistītos jeb autonomos teikumos, un to nosaka dažādi semantiski, stilistiski un apkaimes faktori. Šajā izpratnē pozitīvi tas, ka ir pārbaudes paņēmiens - iespēja paralēli lietot teikumu ar realizētu finìto formu jeb teikuma pilnās realizācijas formu. Latviešu valodā iespējama patstāvīgā vai palīgnozīmē lietota finītā darbības vārda būt nullforma.

3. Redukcija (kontekstuāla un situatīva) kā teksta process jeb tekstveides pan̄ēmiens.

Raksta autore pievienojas uzskatam, ka par sintaktiskajām nullformām latviešu valodā būtu saucamas tikai otrās grupas parādības, bet redukcija ir atšķirīgs process, kas attiecas uz teksta, nevis teikuma sintaksi.

\section{Apzìmējumi}

$\varnothing-$ nulles zīme

\section{Avoti}

1. Belševica, Vizma. 2004. Bille. Rīga: Atēna.

2. Eglīitis, Anšlavs. 1992. Homo novus. Rīga: Zinātne.

3. Gundars, Lauris. 1994. Pēdas stikla kalnā. Rīga: Karogs.

4. Ikstena, Nora. 2004. Dz̄̄ves stāsti. Rīga: Atēna.

5. Janelsiņa, Veronika. 2001. Vēstule. Rīga: Zinātne.

6. Janovskis, Gunars. 1991. Sōla. Pār Trentu kāpj migla. Rīga: Liesma.

7. Joṇevs, Jānis. 2013. Jelgava 1994. Rīga: Mansards.

8. Lìdzsvarots mūsdienu latviešu valodas tekstu korpuss. www.korpuss.lv

9. Repše, Gundega. 1994. Šolaiku bestiārijs. Rīga: Daugava.

10. Skujiņš, Zigmunds. 1996. Jātnieks uz lodes. Rīga: Preses nams.

11. Vētra, Mariss. 1991. Mans baltais nams. Rīga: Teātra anekdotes.

12. www.celotajs.lv

13. www.copeslietas.lv

14. www.diena.lv

15. www.draugiem.lv

16. www.tvnet.lv

17. www.twitter.com

\section{Literatūra}

1. Ahmanova, Olga. 2005. Slovar lingvisticheskih terminov. Moskva: URSS.

2. Beitiņa, Maigone. 2009. Mūsdienu latviešu literārās valodas sintakse. Liepāja: Liepājas Universitāte.

3. Beloshapkova, Vera (red.). 1999. Sovremennyj russkij yazyk. Moskva: Azbukovnik.

4. Crystal, David. 1999. The Penguin Dictionary of Language. Penguin Books.

5. Freimane, Inta. 1985. Vienkāršs teikums un tā paplašināšana. Rīga: LVU. 
6. Ivulāne, Baiba. 2015. Palīgnozīmē lietotu darbības vārdu sistēma latviešu valodā. Promocijas darbs. Rīga: Latvijas Universitāte.

7. Kalnača, Andra. 2013. Darbības vārds (verbs). Latviešu valodas gramatika. Nītina, Daina, Grigorjevs, Juris (red.) Rīga: LU Latviešu valodas institūts, 456-564.

8. Kārklin̦š, Jūlijs. 1974. Praktikums mūsdienu latviešu literārās valodas sintaksēe. I. Rīga: LVU.

9. Lagzdiņa, Sarmīte. 1997. Vienkāršs teikums un tā robežas. Baltu filologiija. VII. Rīga: Latvijas Universitāte, 21-34.

10. Lauze, Linda. 2004. Ikdienas saziņa: vienkāršs teikums latviešu sarunvalodā. Liepāja: LPA.

11. Lokmane, Ilze. 2005. Konsituatīvo saistījumu tipi mūsdienu latviešu valodā. Promocijas darbs. Rīga: Latvijas Universitāte.

12. Lokmane, Ilze. 2013. Vienkārša teikuma formālā (strukturālā) organizācija. Latviešu valodas gramatika. Rīga: LU Latviešu valodas institūts, 710-766.

13. Lokmane, Ilze. 2014. Verbāls sastata izteicējs latviešu valodā. Valoda: nozīme un forma. 4. Kategoriju robežas gramatikā. Rīga: LU Akadēmiskais apgāds, 111-118.

14. Matthews, Peter. 1997. Concise Dictionary of Linguistics. Oxford: Oxford University Press.

15. Mel'chuk, Igor. 1995. Syntactic, or lexical, zero. The Russian Language in the Meaning-Text Perspective. Moskau-Wien, 169-205.

16. Skujiņa, Valentīna (red.). 2007. Valodniecības pamatterminu skaidrojošā vārdnīca. Rīga: LU Latviešu valodas institūts.

17. Testelec, Jakov. 2001. Vvedenie v obshhij sintaksis. Moskva: Rossiskij gosudarstvennyj gumanitarnyj universitet.

18. Trask, Robert Lawrence. 2005. Key Concepts in Language and Linguistics. London and New York: Routledge.

19. Valdmanis, Jānis. 1989. Teikums. Latviešu valodas sintakse. Ceplītis, Laimdots, Rozenbergs, Jānis, Valdmanis, Jānis. Rīga: Zvaigzne, 13-107.

20. Weiss, Daniel. 1995. Remarks on Chapter 7. The Russian Language in the MeaningText Perspective. Mel'chuk, Igor. Moskau-Wien, 206-211.

\section{Summary}

The article provides an analysis of different interpretations of zero signs in linguistics, particularly the zero forms in morphology and syntax. Particular attention is devoted to zero finite verb forms, which help to set the boundaries of syntactic paradigm and therefore differentiate between full and partial realizations of the same syntactic pattern on the one hand, and different patterns on the other.

In Latvian, zero forms of finite auxiliary verbs, copulas, as well as lexical verb būt 'to be' are possible. However, the author argues that none of these are obligatory. This interpretation differs from the one generally accepted in Slavonic linguistics, whereas in Russian zero form of copula in present tense is obligatory. The concept of syntactic zero accepted in this article does not fully correspond to the concept of zero morpheme either.

It has been shown that zero forms should be postulated only in contextually independent utterances, whereas ellipsis refers to syntactic processes in discourse. 